Document downloaded from:

http://hdl.handle.net/10251/104250

This paper must be cited as:

Ginesta Peris, E.; García-Breijo, F.; Primo Yúfera, E. (1994). Antimicrobial activity of xanthatin from Xanthium spinosum L. Letters in Applied Microbiology. 18(4):206-208. doi:10.1111/j.1472-765X.1994.tb00848.x

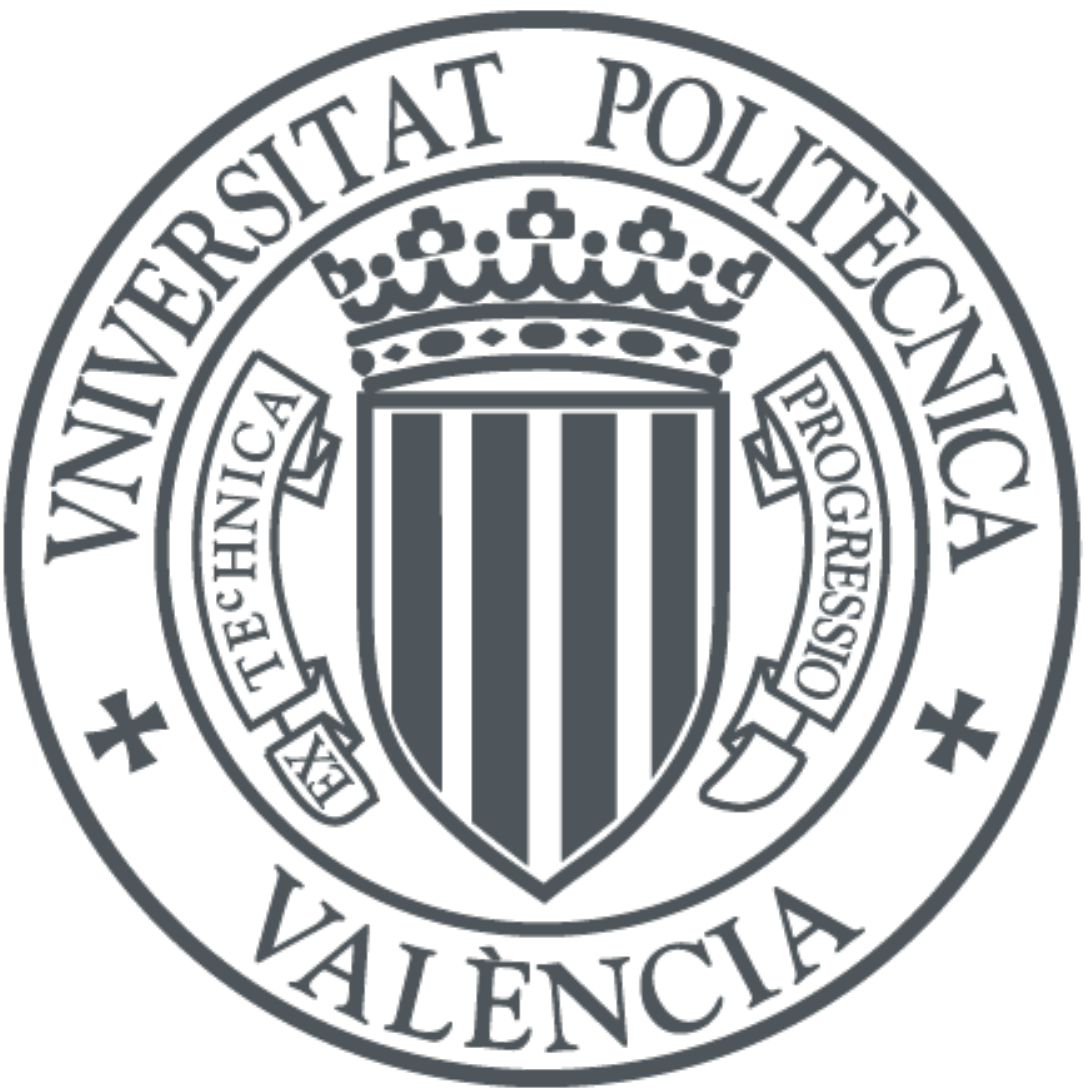

The final publication is available at

https://doi.org/10.1111/j.1472-765X.1994.tb00848.x

Copyright Blackwell Publishing

Additional Information 


\title{
Antimicrobial activity of xanthatin from Xanthium spinosum L.
}

\author{
E. Ginesta-Peris, F.J. Garcia-Breijo and E. Primo-Yúfera \\ Department of Biotechnology, Institute of Chemical Technology, CSIC, Polytechnic University, Valencia, Spain
}

E. GINESTA-PERIS, F.J.GARCIA-BREIJO AND E. PRIMO-YUfera. 1994. Dichloromethane extracts from Xanthium spinosum $\mathrm{L}$. were fractionated and the fractions tested for their bactericidal and fungicidal activity. From the active fraction, a compound was isolated and identified as xanthatin (I). Xanthatin was active against Colletotrichum gloesporoides, Trichothecium roseum, Bacillus cereus and Staphylococcus aureus.

\section{INTRODUCTION}

In an exploratory study of mediterranean flora, with the goal of isolating bioactive compounds, we analysed Xanth-ium spinosum L. (Asteraceae) (Cuñat et al. 1990). Extracts and fractions from $X$. spinosum showed bactericidal and fungicidal activity. In this paper, we report the isolation, identification and antibacterial activity of the active compound.

\section{MATERIALS AND METHODS}

\section{Plant material}

Xanthium spinosum was collected in Valencia and air-dried in shade. A voucher specimen was deposited in the Depart-ment of Botany (Valencia University).

\section{Fractionation, purification and identification of the active compound}

Air-dried $X$. spinosum leaves $(3 \mathrm{~kg})$ were extracted in soxhlet with dichloromethane for $5 \mathrm{~h}$ and the solvent evaporated in a rotavapor. The extract was chromato-graphed on a 60 mesh silica gel column, eluted with a gra-dient of hexane-dichloromethane-acetone, and fractions assayed. The fraction eluted with dichloromethane showed antimicrobial activity and was further refractionated with a silica gel Sep-Pak column (Waters, $10 \mu \mathrm{m}$ ), using dichloro-methane, ethyl acetate and acetone as eluents. The anti-microbial activity was found in the fraction eluted with dichloromethane.

From this fraction, the pure major compound was iso-lated by semipreparative HPLC (column: $8 \times 30 \mathrm{~cm}, 10$ $\mu \mathrm{m}$ particle $\mu$-Porasil; eluents: dichloromethane : ethyl acetate, $95: 5$; flow: $2 \mathrm{ml} \mathrm{min}^{-1}$; detector: Full Range u.v. Diode Array H.P. 85-B).

The structure was determined by infrared, mass spec-trometry and ${ }^{1} \mathrm{H}$-nuclear magnetic resonance.

Xanthatin. $\mathrm{mp}: \quad 114-115^{\circ} \mathrm{C} ;[\alpha]_{\mathrm{D}}^{20}=-19^{\circ} \mathrm{C}\left(\mathrm{C}=1 \cdot 0, \mathrm{CHCl}_{3}\right) ; \mathrm{IR} v_{\max } \mathrm{cm}^{-1}$ (nujol): 1775, 1670, 1590; EIMS m/z: $246\left(\mathrm{M}^{+}, 8\right), 93(13), 43(100), 41(23) ;{ }^{1} \mathrm{H}-\mathrm{NMR}\left(60 \mathrm{MHz}, \mathrm{CDCl}_{3}\right): \delta 1 \cdot 18(\mathrm{~d}, 3 \mathrm{H}), 1 \cdot 85-2 \cdot 18(\mathrm{~m}, 3 \mathrm{H}), 2 \cdot 29(\mathrm{~s}, 3 \mathrm{H}), 2$. $55(\mathrm{~m}, 2 \mathrm{H}), 3 \cdot 16(\mathrm{~m}, 1 \mathrm{H}), 4.5(\mathrm{~m}, 1 \mathrm{H}), 5 \cdot 52(\mathrm{~m}, 1 \mathrm{H}), 6 \cdot 1-6.5(\mathrm{~m}, 3 \mathrm{H}), 7 \cdot 1(\mathrm{~d}, \mathrm{IH}) ;$ Anal. Found: C, $73 \cdot 15 ; \mathrm{H}, 6.95 ;$ Calcd. for $\mathrm{C}_{15} \mathrm{H}_{18} \mathrm{O}_{3}: \mathrm{C}, 73 \cdot 17 ; \mathrm{H}, 7 \cdot 31 \%$.

\section{Microbial strains and growth conditions}

The bacterial cultures used were: Escherichia coli and Sal-monella typhi, Bacillus cereus and Staphylococcus aureus. The bacterial strains were grown on Nutrient Broth Difco at $37^{\circ} \mathrm{C}$ and suspended in saline at $\mathrm{A}_{600}$ O.D. $0 \cdot 5$ concen-tration.

The fungal cultures used were: Colletotrichum gloespo-roides, Fusarium oxysporum, Botrytis cinerea, Penicillium italicum, Aspergillus Aavus and Trichothecium roseum. The fungi were grown on potato dextrose agar for $6 \mathrm{~d}$ at $28^{\circ} \mathrm{C}$.

\section{Bactericidal activity}

The inhibition of the bacterial growth, around a fil ter paper disk (diam. $0.5 \mathrm{~cm}$ ) impregnated with the pre-established amounts of the assay compound, was measured. The medium was Mueller Hinton Agar $(15 \mathrm{ml})$ in Petri dishes $9 \mathrm{~cm}$ in diameter with $1 \mathrm{ml}$ per dish of the bacterial suspension.

The compounds to be tested were dissolved in acetone (1-10/-lg /-1l-1). Ten /-1l of the dissolu tion were added to the paper disk, and the solvent evaporated. Parallel control 
tests, with the pure solvents $(10 \mu \mathrm{l})$ in the disks, were accomplished. The controls showed no inhibition.

Disks containing $10 \mu \mathrm{g}$ of chloramphenicol were also used for comparison.

\section{Fungicldal activity}

The assay compounds to be tested were incorporated in PDA medium; $5 \mathrm{ml}$ of medium were poured into $5 \mathrm{~cm}$ diameter Petri dishes.

The products to be tested were dissolved in acetone (50-500 $\mu \mathrm{g}$ per $100 \mu \mathrm{l})$ and added to the medium $(100 \mu \mathrm{l}$ per dish). All the tests were compared with their corre-sponding controls with the pure solvents in the dishes ( $100 \mu$ l per dish).

The content of one Petri dish, with the fungi grown over $6 \mathrm{~d}$ at $28^{\circ} \mathrm{C}$, in PDA medium, was cut in cylinders (diam. $1 \mathrm{~cm}$ ). Each cylinder was placed in the centre of another dish containing the same medium with the compound to be tested. The dish was incubated at $28^{\circ}$; after $6 \mathrm{~d}$ it was tested for fungi growth.

Results are given in \% of growth (diameter) in compari-son with the control.

As comparative value, activity of imazalil sulphate ( $500 \mu \mathrm{g}$ per dish) was included.

\section{RESULTS}

The purity of the isolated product was confirmed by ana-lytical HPLC and u.v. spectra at three points on the peak, registered by the Dinde Array detector.

By the spectral data, the product was identified as xanth-atin (Fig. 1).

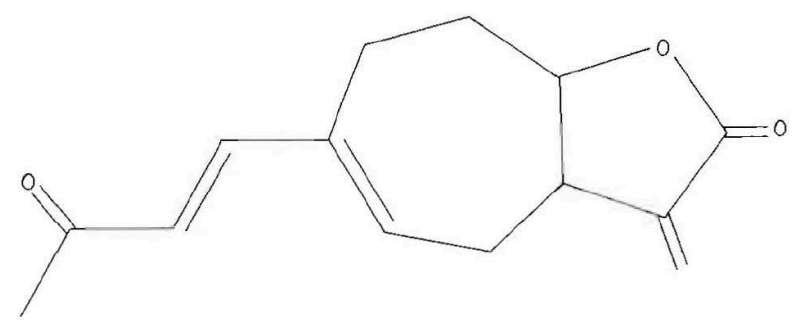

Fig. 1 Xanthatin structure

Xanthatin showed activity against $B$. cereus and Staph. aureus but not against E. coli and Salm. typhi in the bacteri-cidal assay. It also showed high activity against Colletotrichum gloesporoides and Trichothecium roseum, very low activity against $F$. oxysporum and Botrytis cinerea but none against Penicillium italicum and Aspergillus jlavus, in the fungicida! assay.

Table 1 Bactericidal and fungicidal activities of xanthatin

\begin{tabular}{|c|c|c|c|c|c|c|}
\hline \multirow[b]{2}{*}{ Compound } & \multicolumn{3}{|c|}{ Bactericidal activity* } & \multicolumn{3}{|c|}{ Fungicidal activity $\dagger$} \\
\hline & $\begin{array}{l}\text { Dose } \\
\text { ( } \mu \mathrm{g} \text { per disk) }\end{array}$ & $\begin{array}{l}\text { Bacillus } \\
\text { cereus }\end{array}$ & $\begin{array}{l}\text { Staphylococcus } \\
\text { aureus }\end{array}$ & $\begin{array}{l}\text { Dose } \\
\text { ( } \mu \mathrm{g} \text { per ml) }\end{array}$ & $\begin{array}{l}\text { Colletotrichum } \\
\text { gloesporoides }\end{array}$ & $\begin{array}{l}\text { Trichothecium } \\
\text { roseum }\end{array}$ \\
\hline \multirow{4}{*}{ Xanthatin } & $\cdot 100$ & 18 & 18 & 100 & 25 & 20 \\
\hline & 50 & 16 & 14 & 50 & 40 & 30 \\
\hline & 25 & 15 & 13 & 25 & 60 & 60 \\
\hline & 10 & 12 & 10 & 10 & 85 & 75 \\
\hline Chloramphenicol & 10 & 17 & 14 & & & \\
\hline Imazalil sulphate & & & & 100 & 5 & 20 \\
\hline
\end{tabular}

* Bactericidal activities are given in $\mathrm{mm}$ of growth inhibition around the disks. Mean of three tests; maximum range \pm 2 mm.

$\dagger$ Fungicidal activities are given in $\%$ of growth in comparison with the blank. Mean of three tests; maximum range \pm 4 .

Blank growth: C. gloesporoides, $3.9 \mathrm{~cm} ; T$. roseum, $2.0 \mathrm{~cm}$. 
Table 1 shows the fungicidal and bactericidal activities of the compound. Chloramphenicol and imazalil sulphate values are also included.

\section{DISCUSSION}

Xanthatin was previously isolated from Xanthium stru-marium L. (Pashchenko and Pivnenko 1964), Pul icaria crispa (Bohlmann et al. 1979), X. orientale (Bohlmann and Zdero 1981), X. indicum (Bohlmann et al. 1982), X. spinosum (Omar et al. 1984) and X.pungens (Ahmed et al. 1990).

The structure of xanthatin was identified by Deuel and Geissmann (1957) as a product obtained from xanthinin.

Xanthatin was active against the two Gram-positive bac-teria tested but not against the Gram-negative; both bac-teria are common food contaminants.

Xanthatin was less active than chloramphenicol against Staph. aureus and B. subtilis. At $50 \mu \mathrm{g}$ per disk it was as active as chloramphenicol at $10 \mu \mathrm{g}$ per disk, against Staph.aureus.

Xanthatin showed lower activity than imazalil sulphate against $C$. gloesporoides, but similar activity against $T$. roseum, at doses of $100 \mu \mathrm{g} \mathrm{m}]^{-1}$. Colletotrichum gloespo-roides and $T$. roseum are phytopathogenic fungi.

\section{REFERENCES}

Ahmed, A.A., Jakupovic, J., Bohlmann, F., Regaila, H.A. and Ahmed, A.M.( 1990) Sesquiterpene lactones from Xanlhium pungens. Phylochemislry 29,2211-2215.

Bohlmann, F. and Zdero, Ch. ( 1981 ) An isomer of xanthanol from Xanthium orienta/e. Phytochemistry 20, 2429-2430.

Bohlmann, F., Knoll, K.H. and EI-Elmary, N.A. (1979) Neuartige sesquiterpenlactone aus Pu/icaria crispa. Phytochemwry 18, $1231-1233$.

Bohlmann, F., Singh, P., Joshi, K.C. and Singh, C.L. (1982) Xhanthanolides from Xanlhium indicum. Phylochemislry 21, $1441-1443$

Cuñat, P., Primo, E., Sanz, l., Garcerá, M.D., March, C.,Bowers, W.S. and Martínez-Pardo, R. (1990) Biocidal activity of sorne Spanish mediterranean plants. Journal of Agricullural and Food Chemislry 38, 497-500.

Deuel, P.G. and Geissmann, T.A. (1957) Xanthinin II. The structure of xanthinin and xanthatin. Journal of the American Chemical Sociely $79,3778-3783$.

Drnar, A.A., Elrashidy, E.M., Ghazy, N.A., Metwally, A.M., Ziesche, J. and Bohlmann, F. (1984) Xanthanolides from Xanlhium spinosum. Phylochemistry 23, 915-916.

Pashchenko, I.M.M. and Pivnenko, G.P. (1964) Phytochemical study of Xanthium slrumarium. Farmalsewl 19(3), 16-19. C.A. 1964, 5442. 